\title{
Approaches to the Frankish community in the Chronicle of Fredegar and Liber
}

\section{Historiae Francorum}

\section{Richard Broome}

Notions of community are crucial to how we understand our place in society and our role in the world around us. Of course, very few people consider themselves to belong to just one community, and the interactions between the different communities to which we belong are intrinsic in forming our self-identities. Yet the precise meanings of communal identities can change based on the perceptions of those who identify as part of a community, even when the label used remains the same. A person living in the UK today may identify as British, English, Scottish etc., but these labels do not necessarily mean the same thing as they did in the first half of the twentieth century or in the nineteenth century. This was just as true in the early medieval period as it is today, although the only witnesses we have to notions of identity and community in the pre-modern era are the surviving sources - whether written or archaeological. ${ }^{1}$ While this means we have a more limited pool of opinions to draw upon, it seems reasonable to assume that our sources generally reflect the prevalent discourses of the times at which they were produced, even if - as we shall see - each source provides an individual perspective on these discourses. ${ }^{2}$

The purpose of this paper is to examine the notion of Frankish community - that is, the communal identity of those living within the regnum Francorum - as it emerged, developed and changed during the seventh century and into the early-eighth. This examination will

\footnotetext{
I am grateful to Roger Collins for his response to the original version of this paper, on which some of the points herein are based. I would also like to thank Ian Wood for his comments on early drafts of the present paper. Any errors in this final version, of course, remain my own.

${ }^{1}$ For the most recent study of notions of community in the early medieval period, see Pohl, Gantner and Payne (eds) 2012. See also Goetz, Jarnut and Pohl (eds) 2003; Corradini, Diesenberger and Reimitz (eds) 2003.

${ }^{2}$ On the importance of contemporary discourses for informing our sources, see Goffart 1988.
} 
focus on two historical texts, the so-called Chronicle of Fredegar, composed c.660, ${ }^{3}$ and Liber Historiae Francorum (henceforth $L H F$ ), composed in $726 / 7 .{ }^{4}$ These sources and the approaches of their authors to community are particularly relevant when considering the idea of continuity in the seventh century precisely because, for all their differences, each of these authors presents a history of the Frankish kingdoms that focusses above all on the Franks themselves, an approach that differs significantly from those of earlier and later authors. The period in which they wrote, therefore, sits between two watersheds in how authors in the Frankish kingdoms presented their community, one at the turn of the seventh century and the other in the middle of the eighth century.

The sixth century attitude is epitomised by Gregory of Tours, and particularly his Decem Libri Historiarum (henceforth Histories), composed at the end of the sixth century. Unlike the two sources on which we shall focus here, Gregory did not attempt to write a 'history of the Franks'. Nor were the Franks as a group of particular concern to him, except to show where they fitted into his community; the Christian community of Gaul. It is the latter that forms the axis about which the world of the Histories turns. It is worth noting, though, that despite Gregory's ambivalence towards the Franks, both of our authors were happy to use his work as a basis on which to build their own 'histories of the Franks'. Nevertheless, both authors altered the material they found in Gregory's work and added to it where necessary, although the $L H F$-author did not take anything from the Chronicle of Fredegar, and changed what he took from Gregory in different ways than had the earlier author. This basis in Gregory's work suggests a continuity of ideas across the seventh century and shows that,

\footnotetext{
${ }^{3}$ For the date of the work, see Collins 2007: 105-7.

${ }^{4}$ For the date, see Gerberding 1987: 1.

5 James 1998: 51-66.
} 
while some alterations took place, such material remained relevant in discussions about the Frankish past into the eighth century. ${ }^{6}$

The mid-eighth century watershed was informed above all by the rise to power and - in 751 - royal usurpation of the Carolingian family, and the concurrent expansion of Frankish hegemony over other peoples. These processes led to an approach to community that combined the emphasis on the Franks found in our two sources with an emphasis on a community of Christians that would not have been out of place in the world of Gregory of Tours. Thus, in the sources of the late-eighth and early-ninth centuries, for example the Continuations to the Chronicle of Fredegar (Fredegarii continuationes) and the Annales Mettenses Priores, we see the continued importance of Frankishness balanced against the desire to create and present a Christian community composed of many peoples. ${ }^{7}$ Again, this was not a complete break with previous approaches because both sources were based on the account found in $L H F$, and the Continuations were added to the Chronicle of Fredegar. But the mid-eighth century does mark a significant shift in the way authors approached their community.

Here we shall concentrate on just one aspect of the discussions that can be found in all the sources mentioned above: how the authors of the Chronicle of Fredegar and LHF approached, imagined and presented the Frankish community, not just by commenting on their own times (the mid-seventh and early-eighth centuries respectively), but also by interpreting - and re-interpreting - the past. This is not an attempt to recreate the reality of a Frankish community in the seventh century; rather, it is an analysis of what these authors thought it was and what it meant to them. ${ }^{8}$ To this end the focus will be on several key features of their narratives: how the authors used the term 'Franks'; how and to where they

\footnotetext{
${ }^{6}$ Reimitz forthcoming. I would like to thank Helmut Reimitz for letting me read a copy of this in advance of publication.

${ }^{7}$ Reimitz forthcoming; Broome forthcoming. On this aspect of Charlemagne's imperial coronation, see MayrHarting 1996: 1113-1133.

${ }^{8}$ For such an approach to modern communities, see Anderson 1983.
} 
traced the origins of the Frankish people and their kings; and the role kings were expected to play within the community. What we shall see is that even though each author provided a different vision of the Frankish community in which they lived, both ultimately relied upon certain fundamental ideas about that community. There are, however, some important points to be made about each before beginning our particular inquiry. First, it is worth mentioning that both the Chronicle of Fredegar and $L H F$ have traditionally been found wanting when compared to Gregory of Tours's Histories. ${ }^{9}$ This judgement largely rested on the supposed quality and reliability of each author's narrative, but recent scholarship has seen the balance somewhat restored with efforts made to study these texts in their own right, and it is upon these efforts that the present study seeks to build. ${ }^{10}$ Nevertheless, there are issues with each source that need to be addressed in order to fully understand them.

To begin with 'Fredegar', we shall refer throughout to an author of that name, even though this was almost certainly not the name of the compiler of the chronicle that bears the name. ${ }^{11}$ Indeed, as already mentioned, most of the scholarship of the past century has been concerned with the issue of who wrote the chronicle and when. ${ }^{12}$ The current common consensus is that the chronicle as we have it now was compiled by a single author working around the year $660 .{ }^{13}$ Nevertheless, this conception of a single author has been nuanced by the understanding that he or she was rather a 'compiler' who worked from older sources that were incorporated into the chronicle either in part or wholesale. ${ }^{14}$ Thus, while it is difficult to assign the views expressed in the Chronicle to any one person or point in time, the text as a whole remains an important witness to attitudes that prevailed during the first half of the

\footnotetext{
${ }^{9}$ See Gerberding 1987: 2-3.

${ }^{10}$ Most recently Fischer forthcoming; Dörler 2013: 23-43. See also Collins 2007; Wood 1994: 359-66; Fouracre and Gerberding 1996: 79-87; Gerberding 1987.

${ }^{11}$ See Collins 1996: 81-3.

${ }^{12}$ A debate begun by Bruno Krusch (1882), who argued for multiple authorship. Krusch's main opponent was Ferdinand Lot (1914), who outlined an argument for single authorship. Wallace-Hadrill (1960: xiv-xx) provides an overview of the development of this debate, followed by his own argument in favour of multiple authorship (ibid., xxi-xxv). See also Goffart 1963: 206-41; Collins 1996: 91-6.

13 Goffart 1963.

${ }^{14}$ Collins 2007: 46-55; Reimitz 2013: 257-301.
} 
seventh century, and which may still have seemed relevant to the later compiler: as we shall see, there is at least some coherence of opinion about certain issues relating to the Franks.

$L H F$, meanwhile, has not been the subject of such debate, in part because the author gives the year of composition within the text: Theuderic IV 'is now in the sixth year of his reign', ${ }^{15}$ that is $726 / 7$, with no reason for doubting this. ${ }^{16}$ Yet it was traditionally overshadowed in modern scholarship by the chronicles and annals produced during the 'Carolingian Renaissance' of the late-eighth and early-ninth centuries - even if it remained one of the most widely read historical narratives during the medieval period. ${ }^{17}$ This overshadowing has now been dispelled and more recent debates have focussed on exactly where the author wrote and whether he or she was lay or ecclesiastical, ${ }^{18}$ as well as the relative influence of 'Germanic' (or 'heroic') and Christian traditions on the author. ${ }^{19}$ These debates have not necessarily ended, but they do not impinge too greatly on our own inquiry. Let us turn, then, to how each of these authors approached the Frankish community.

\section{Constructing the Frankish Community}

While the 'Franks' (Franci) are found in sources from the late Roman period, ${ }^{20}$ the first major narrative works to feature them in anything resembling a leading role did not appear until the second half of the sixth century. Of these, the most famous is probably Gregory of Tours' Histories. But it is important to remember the Franks were not Gregory's primary focus, and the Franci who feature in his work tend to be important individuals such as kings: the Franks as a collective group have very little active role in Gregory's work. Indeed, the bishop may have been actively trying to supress the emerging concept of a Frankish

\footnotetext{
15 This and all other translations - unless noted - are my own.

${ }^{16}$ LHF, 53.

${ }^{17}$ Fouracre and Gerberding 1996: 86; Gerberding 1987: 3 .

${ }^{18}$ See Gerberding 1987: 152; Nelson 1996: 195.

${ }^{19}$ Compare Gerberding 1987: 159-63 with Dörler 2013.

${ }^{20}$ For example, Ammianus Marcellinus, xv.5.11. See Wenskus 1961: 512-41; Zöllner 1970.
} 
communal identity. ${ }^{21}$ Instead, the most important community to Gregory was the Christian community of Gaul, of which all the various inhabitants of the region were part and which the Merovingian kings ruled as reges Galliae, rather than specifically as reges Francorum. ${ }^{22}$ Yet Gregory's Histories formed the foundation for those who followed him in writing about the Frankish kingdoms via a six-book version of his text that dropped the last four books entirely and excised much of the ecclesiastical material that had been so important to Gregory's purpose. This was not necessarily an attempt to make the Histories more 'Frankish', but it certainly served the purpose of authors who were more concerned with the Frankish community than Gregory had been. ${ }^{23}$

$L H F$, written over a century later, offers a rather different vision of the Franks than Gregory had. Although based on the six book version of Gregory's Histories for much of its narrative, $L H F$ gives the Franks a far more active role and the collective group is as much a leading historical protagonist as are any of the named individuals who feature in the work; perhaps more so, since the Franks choose their rulers, a point to which we shall return shortly. LHF's historical narrative, then, is about the Frankish community in the same way Gregory's is about the Christian community. There is a need for clarification here, though, because the Franks of $L H F$ are not the general inhabitants of the regnum Francorum, they are the Neustrians; that is the nobility of just one of the three Frankish sub-kingdoms or Teilreiche. ${ }^{24}$ Thus, while $L H F$ represents a specifically Frankish history in a way that neither Gregory's or Fredegar's works do, it shows a very particular understanding of what it meant to be a Frank. Nevertheless, the beginnings of this increasingly Frankish focus can be seen in the Chronicle of Fredegar, even if this earlier work lacks LHF's narrower focus. Overall, the chronicle - with its use of earlier material and general interest in events outside Francia -

\footnotetext{
${ }^{21}$ Reimitz forthcoming.

${ }^{22}$ Reimitz forthcoming.

${ }^{23}$ Helmut Reimitz has been leading the way in this interpretation of how Gregory's Histories were used by later authors. See Reimitz 2003; 2006; 2012; forthcoming.

${ }^{24}$ On the subject of the sub-kingdoms, see Ewig 1976.
} 
shows an approach even more universal than Gregory's had been, an approach that continues in the section narrating the first half of the seventh century. ${ }^{25}$ Yet this section (known as the Fourth Book) and the information found in interpolations in earlier sections - derived from older material such as Eusebius-Jerome's Chronicle and Gregory's Histories - show an increased interest in the Franks. Likewise, from around 613 - the year Chlothar II became sole king of a reunited regnum Francorum - the Franks begin to take a more active role in the narrative, and the Frankish kingdoms have centre stage in the Fourth Book, although Fredegar continues to provide information about other regions, for example the Byzantine Empire, information which is largely lacking in $L H F .^{26}$

Both Fredegar and the $L H F$-author used the term Franci without the need for qualification; they and their audiences must therefore have had some idea of what a 'Frank' was, and there must have existed some shared conception of the Franks as a communal group. Yet the precise details of these understandings were open to interpretation, and our authors show us a Frankish community divided into regional sub-groups. The regnum Francorum of the seventh century was composed of three Teilreiche; Neustria, Austrasia and Burgundy: together the inhabitants of these kingdoms were the members of the Frankish community. These geographical divisions and their associated labels were the primary way to identify members of the Frankish community, and while members of these three groups were all undeniably Frankish, their exact natures and the relationships between them were presented differently by our two authors.

Fredegar presents the three groups as equal but distinct Frankish groups, although the narrative of Book Four focusses more on the Burgundians and Austrasians than on the Neustrians. As already mentioned, $L H F$ has a different emphasis, since the author only uses the unqualified term Franci to refer to the Neustrians, a usage nearly unique to this source,

\footnotetext{
${ }^{25}$ Fischer forthcoming.

${ }^{26}$ Fredegar, iv.23,63-6,81. See Fischer forthcoming.
} 
but occasionally alluded to in late-seventh century hagiographical texts, for example the Vita Balthildis. ${ }^{27}$ The implication here would seem to be that the author saw the Neustrians as in some way the 'true' Franks, the direct descendants of those Franks who had originated in Troy (see below) and followed Clovis I in converting to Christianity. Nevertheless, the $L H F$ author allows that the Austrasians and Burgundians are Franks, and they are referred to as such on several occasions in the narrative. The Austrasians are called Franci superiores, ${ }^{28}$ a term which may be based in Roman geographical terminology rather than status, while elsewhere we learn that the 'Burgundians and Austrasians made peace with the rest of the Franks' ${ }^{29}$ Similarly, Austrasia is referred to as a 'Frankish kingdom' ${ }^{30}$ The Austrasians themselves were composed of at least one further sub-group: the Ripuarians, who were the inhabitants of the area around Cologne. ${ }^{31}$

The Burgundians represent an interesting case because their kingdom was based on the former Burgundian kingdom that had been brought to an end by the sons of Clovis I and Clothild in 534. ${ }^{32}$ There were, then, two Burgundian groups in the accounts of our sources, the first the original 'ethnic' Burgundians and the second the Frankish rulers of the Frankish kingdom of Burgundy. Fredegar clearly distinguishes between these two groups, referring to the first simply as Burgundiones and the second by the use of the unusual term Burgundaefarones. ${ }^{33}$ The $L H F$-author, on the other hand, does not make such a distinction; for him both groups simply are Burgundiones. Unfortunately it seems impossible to say whether Fredegar's usage was a stylistic quirk that fell out of favour - although it was not unique to that author ${ }^{34}$ - or whether there was a shift in the ethnic labelling or even self-

\footnotetext{
${ }^{27}$ For example, Vita Balthildis, 10. For discussion of the text, see Fouracre and Gerberding 1996: 97-118. On this use of the term Franci, see Gerberding 1987: 167-8.

${ }^{28} L H F, 36,41$.

${ }^{29} \mathrm{LHF}, 40$.

${ }^{30} \mathrm{LHF}, 27$.

${ }^{31}$ LHF, 38; Gerberding 1987: 76.

${ }^{32}$ Gregory, Histories, iii.5-6, 11. See Wood 1994: 51-4.

${ }^{33}$ Murray 1983: 93; Halsall 1998: 151. See also the discussion in Aubrichs 2007: 180-1.

${ }^{34}$ Jonas of Bobbio, Vita Columbani, i.26, ii.21.
} 
identification of the Burgundians during the second half of the seventh century. What we can conclude, though, is that both authors saw the Burgundians of the seventh century, along with the Neustrians and Austrasians, as Frankish, and as being part of an over-arching Frankish community that incorporated several sub-groups.

This notion that the Frankish community was more than the sum of its parts can be seen in the way crises of the kingdom are narrated by the authors. Times of crisis end with the determined action of the Frankish sub-groups acting in concert under a single leader. Thus, the wars between the brothers Theudebert II and Theuderic II and their cousin Chlothar II that dominated the early years of the seventh century were brought to an end when the Burgundians and Austrasians sided with Chlothar and turned against Theuderic's son Sigibert II and his great-grandmother and regent Brunhild. ${ }^{35}$ Such wars may sometimes appear to be the activities of kings, but it is clear that the important decisive factor was the will of the Franks. Fredegar tellingly refers to a process called the iudicium Francorum, through which a united group of Franks from all three kingdoms could make legal decisions, even between rival kings. ${ }^{36}$ Likewise, in $L H F$ times of particular crisis are those when peaceful interaction breaks down. Particularly noteworthy is the war which followed the deaths of the mayor Pippin II and King Dagobert III in 714-15, in the opening battle of which the author explicitly refers to Franci fighting other Franci. ${ }^{37}$ It is possible that, while the war escalated, this particular battle only involved Neustrians, but given the involvement of Pippin's widow Plectrude, it is not impossible the author is referring to both Neustrians and Austrasians simply as Franci, perhaps in order to emphasise the direness of the situation.

In both texts, then, we can detect a desire for unity within the community despite the acceptance of the existence of separate Teilreiche. Chlothar II was seen as a good king above

\footnotetext{
${ }^{35}$ Fredegar, iv.40-2; LHF, 40.

${ }^{36}$ Fredegar, iv.37, 40; the process is also hinted at, though not named at Fredegar, iv.53. See Reimitz forthcoming.

${ }^{37} \mathrm{LHF}, 51$.
} 
all because he successfully united the separate kingdoms. But Fredegar acts as a witness to the continuing need or desire for Neustria and Austrasia (but not Burgundy) to have their own kings. He does not criticize Chlothar for setting up his son Dagobert I as sub-king in Austrasia, nor Dagobert for doing the same with his own son Sigibert III. ${ }^{38}$ The $L H F$-author is more ambivalent about the idea of a divided kingdom since he is able to cite several occasions when such divisions of rule led to or contributed to hostilities between the Frankish groups. ${ }^{39}$ We must also remember, though, that for most of the later author's life the Franks were ruled by a single king reigning from Neustria. Not only could this have contributed to his sense that the Neustrians were the true Franks, it must also have coloured his opinion about the idea of having a separate king based in Austrasia, a practice that had fallen out of use after the death of Dagobert II in $679,{ }^{40}$ with the brief exception of Charles Martel's Austrasian King Chlothar IV in $717-18 .{ }^{41}$ We shall return to the attitudes these authors held towards kingship shortly, but for now let us turn to a feature of their narratives which particularly highlights their awareness of the idea of a Frankish community: the story of its origin.

\section{From Trojans to Franks - the origins of the community}

One crucial way in which the narratives of Fredegar and $L H F$ differ from that of Gregory of Tours is in their tracing the origins of the Franks and their kings. ${ }^{42}$ Gregory had claimed he had not been able to learn anything about the origins of Frankish royal power from his sources, and did not narrate the origin of the Frankish people, other than that they had emerged from Pannonia. ${ }^{43}$ Both Fredegar and the $L H F$-author, however, claimed the Franks were descended from Trojans who had escaped the fall of Troy. While some elements of this

\footnotetext{
${ }^{38}$ Fredegar, iv.47, 75 .

${ }^{39} \mathrm{LHF}, 40,43,45-7,51-3$.

${ }^{40}$ On Dagobert II, see Picard 1991; Fouracre 2008.

${ }^{41} L H F, 53$.

${ }^{42}$ Gerberding 1987: 11-30.

${ }^{43}$ Gregory, Histories, ii.9.
} 
story are common to both sources, they ultimately tell two quite different versions of the Trojan origin legend. ${ }^{44}$ The key point for our purpose, though, is the reporting of the story itself, which shows that both Fredegar and the $L H F$-author were more clearly engaged with and aware of a Frankish community than Gregory had been, and each was interested in exploring the origins of this community in order to show continuity between the legendary past and the present. Before turning to the purpose that such stories served, though, let us briefly recount what each author says.

Fredegar's Trojan origin story appears first as an interpolation in the Chronicle of Eusebius-Jerome (Book Two), with a further interpolation adding information about the Trojan origin of the Romans. The story also appears in a condensed form as an interpolation in Gregory's Histories (Book Three). The thrust of this narrative rests on successive splittings of the original Trojan group: first between the Frigians - the followers of Friga - who settle on the Danube and those who settle in Macedonia, becoming incorporated into the Macedonian people; the Frigians then divide into the Franks - the followers of Francio, who travel to the Rhine - and the Turks - the followers of Torcoth, who remain on the Danube. ${ }^{45}$ The Franks are subsequently conquered by Pompey and the Romans, but ally with the Saxons to 'cast off his authority'. After they had established themselves on the Rhine, no other ruler or people was able to conquer the Franks, who in turn were able to subjugate other peoples. ${ }^{46}$ $L H F$ 's narrative also begins with a division of the Trojans, this time between those who follow Aeneas to Italy and those who follow Priam and Antenor to Pannonia. After driving the Alans from the Maeotic marshes, the latter are named 'Franks' by Emperor Valentinian; 'frank' supposedly meaning fierce 'in the Attic language' ${ }^{47}$ But the Franks refuse to pay

\footnotetext{
${ }^{44}$ On the development of the Trojan origin legend of the Franks see N. K. Yavuz, in this volume.

${ }^{45}$ Fredegar, ii.4-6, iii.2.

${ }^{46}$ Fredegar, ii.6, iii.2.

${ }^{47} \mathrm{LHF}, 1-3$.
} 
tributes to the Romans and flee to the far end of the Rhine, where they establish their own laws and line of kings, freeing themselves from Roman authority. ${ }^{48}$

As well as explaining the origins of the Franks, these narratives also explain the origins of the kings of the Franks, or more specifically the Merovingian dynasty. In each case the kings are descended from Priam, the man who leads the Trojans from their fallen city and in each we are also shown a transition from non-royal to royal rule, but again, the precise details change. In Fredegar's account (in Book Two), Priam, Friga and Francio are described as reges, but after Francio's death the Franks are ruled by duces. ${ }^{49}$ Later (in Book Three) we learn that the Franks again decided to be ruled by a 'long-haired king', and chose Theudemer, son of Ricimer as their king; this information is straight from Gregory of Tours, but Fredegar adds that Theudemer was descended from Priam. ${ }^{50}$ Likewise, whereas Gregory simply said the next king, Chlodio, ruled around the same time, Fredegar makes him Theudemer's son and successor. This provides a link from Priam to the rest of the Merovingian line, but the link remains in doubt because Fredegar leaves open the question of whether Chlodio's successor, Merovech, was conceived by Chlodio or by the Quinotaur, a mysterious seamonster that supposedly 'desired the king's wife'. ${ }^{51}$ In $L H F$, meanwhile, Priam and Antenor and their sons Marchomir and Sunno are principes. ${ }^{52}$ After Sunno's death the Franks decide they wish to be ruled by kings; Marchomir recommends the Franks make his son, Faramund, their 'long-haired' king, 'so they might have one king like other peoples'. ${ }^{53}$ Here Faramund is the father of Chlodio and the Merovingian dynasty is still descended from Priam, but more

\footnotetext{
${ }^{48} \mathrm{LHF}, 4$.

${ }^{49}$ Fredegar, ii.4-6.

${ }^{50}$ Fredegar, iii.9; Gregory, Histories, ii.9. See also Fredegar, iii.5.

${ }^{51}$ Fredegar, iii.9. On Fredegar's use of this story to criticize the Merovingian family, see Wood 2003: 149-53.

${ }^{52} L H F, 1,4$. The names Marchomir and Sunno were known to Gregory, even if not in a Trojan context:

Gregory, Histories, ii.9.

${ }^{53} \mathrm{LHF}, 4$.
} 
firmly so because in $L H F$ there is no story hinting at a monstrous parentage for Merovech; rather, he is 'of Chlodio's family'. ${ }^{54}$

All of this legendary material seems rather suspicious to a modern audience more familiar with the Trojan War and its aftermath as told by Homer and Virgil, ${ }^{55}$ but the link to Troy was just one of the possible stories used in the early medieval origines gentium; another was the Scandinavian origin used by Paul the Deacon for the Lombards. ${ }^{56}$ When the Franks first linked themselves to the Trojans is unknown, since Fredegar is the legend's earliest witness, but surely not its inventor. One particularly plausible theory is that they were influenced by their interactions with the third- and fourth-century Gallo-Romans, who had their own legends about the Trojan origins of both the Gauls and the Romans, ${ }^{57}$ although it may not have been until the sixth century that members of the Merovingian dynasty began explicitly using the legend to support their authority. ${ }^{58}$ If this was the case, it seems likely Gregory of Tours knew of the legend but chose not to mention it because it did not fit with his conception of history. ${ }^{59}$

Regardless of how long the idea of Frankish origins in Troy had been in circulation or where such stories came from, this was clearly an important part of how the Frankish community was understood in the seventh and eighth centuries. Indeed, it was so important to the $L H F$-author that he used it as the opening for his work: there was no history of the Franks without their Trojan origin. While the story appears somewhat more incidental to the overall narrative of the Chronicle of Fredegar, the information was clearly worth adding to the accounts the compiler had at his disposal. But what does this information tell us about the

\footnotetext{
${ }^{54} \mathrm{LHF}, 5$.

55 See Yavuz, in this volume.

${ }^{56}$ Paul the Deacon, Historia Langobardorum, i.1-18. See also Origo gentis Langobardorum, 1. It is worth noting Fredegar was aware of this Lombard origin story; see Fredegar, iii.65.

57 The reasons for accepting this theory are most clearly laid out in Barlow 1995: 88-90. See also Wood 1995: 51-2.

58 Barlow 1995: 93.

${ }^{59}$ Barlow 1995; Wood 1995: 49-53; Reimitz, forthcoming.
} 
understanding of the Frankish community? First, it shows the Franks believed themselves to have a long and illustrious history, comparable to that of the Romans. Second, it shows the Franks were at least the equals, if not the superiors of the Romans since they had defeated either the Romans themselves or enemies the Romans were incapable of defeating. ${ }^{60}$ Their subsequent independence from the Romans must also have been seen as particularly important, especially since Fredegar links this with the idea that the Franks had subjugated other peoples, perhaps showing them to be the new imperial power. Third, we are provided with something of an etymology for the collective name the Franks used to refer to themselves: it was either taken from one of their legendary kings or a representation of their fierceness ${ }^{61}$ but either way was an important foundational moment for the Franks as a people. Fourth, we see the moment when the Franks gained royal leadership, even if they had already been ruled by the ancestors of this first king for some time. Neither author explains the significance of the kings being 'long-haired', and this aspect of Merovingian kingship has been an unresolved point of debate since the ninth century, ${ }^{62}$ but we can say at least it was a central - if now obscured - aspect of Merovingian kingship. Nevertheless, this point of 'kingmaking' may be the most significant aspect in both origines because it represents the constitutional link between the Franks and their kings: the Franks choose their king, just as they choose to be ruled by a king. The point seems more well-developed in $L H F,{ }^{63}$ where the author also connects this moment with the time the Franks began to have laws (borrowing from the Prologue to the Lex Salica) ${ }^{64}$ and also uses similar language for the accessions of several kings and mayors, especially from the reign of Dagobert I onwards. Let us, therefore, now consider the attitudes to these kings in more detail.

\footnotetext{
${ }^{60}$ Note, both Gerberding 1987: 18 and Dörler 2013: 30-1 play down the importance of the relationship between Franks and Romans in their readings of $L H F$.

${ }^{61}$ Isidore of Seville (Etymologies, ix.ii.101) cites both of these as possible origins for the name of the Franks.

${ }^{62}$ See, for example Einhard, Vita Karoli Magni, 1; Dutton 2004: 3-42; Diesenberger 2003.

63 The author's phraseology here may be a reference to I Samuel, 8; 5. See Dörler 2013: 39-40.

${ }^{64}$ Compare LHF, 4 to Pactus legis Salicae, Prologue.
} 


\section{The role of kings}

Despite the active role of the Franks in our sources, kings retained a central place in the community as its rulers. In a sense, kings were the embodiment of the community's wellbeing, with good kings strengthening the community and bad kings weakening it. It is important to remember, though, that the idea of what constituted 'good' and 'bad' kingship was not static across the early medieval period and, although there was some sense of continuity, $L H F$ and the Chronicle of Fredegar are particularly useful for highlighting such changing attitudes. While each contains a 'history of the Franks' this history was impossible to relate without also mentioning the kings of the Franks, whose actions and personalities are judged by the authors.

The Chronicle of Fredegar shows a belief that good kings were those who actively asserted their authority through force, and were able to exert their will on their subjects. Thus, Chlothar II was a good king because he united the three Teilreiche and worked closely with the leading men of each, ${ }^{65}$ while his son Dagobert receives a more mixed sentence because even though he showed moments of strength, particularly when ruling as his father's sub-king in Austrasia, he became corrupt and decadent after settling in Neustria. ${ }^{66}$ This desire for strong kings is reinforced by a tale concerning the wedding of Childeric I and Basina interpolated into Fredegar's epitome Gregory's Histories. On their wedding night, Basina sends Childeric from their bed and tells him to report what he sees outside. First he sees 'beasts like a lion, a unicorn and a leopard', then 'beasts like bears and wolves', and finally 'smaller beasts like dogs and even smaller beasts twisting and pulling at each other' ${ }^{67}$ Basina reveals the significance of these visions as representing Childeric's descendants: the lion is their son, and the unicorn and the leopard his sons; the wolves and bears are the latters'

\footnotetext{
${ }^{65}$ Fredegar, iv.42.

${ }^{66}$ Fredegar, iv.60.

${ }^{67}$ Fredegar, iii.12.
} 
offspring; the dogs and smaller beasts represent what will happen in the following generations, 'when the support (columpna) of the kingdom falls apart': men who rule with the courage of dogs, while even smaller creatures - the people - 'destroy each other without the fear of rulers'.

The tale seems to be an attack on those kings who did not live up to the standards set by Childeric's son Clovis I - 'the bravest of all kings' in Fredegar's words - and a literal reading would imply that the Frankish kingdoms reached their nadir at the end of the sixth century, under the descendants of Kings Sigibert I and Chilperic I, all of whom came to their thrones as minors and acted under the guidance of the queens-regent Brunhild and Fredegund. If we combine this tale with Fredegar's general damnatio memoriae of Brunhild, ${ }^{68}$ we can sense a distrust of child-kings and over-mighty regents running through the Chronicle: when weak kings were ruled by others, they could not fulfil their correct royal roles, and a risk ensued that the kingdoms would fragment and descend into civil war. Such civil wars required the Franks to unite under a strong ruler to bring them to an end, as they did when the Austrasians and Burgundians abandoned Brunhild for Chlothar II.

We receive a somewhat different vision of kingship from $L H F$. This source emphasizes the unity of the kingdoms under one king to an even greater degree than the Chronicle of Fredegar, although this should not surprise us because by the time its author wrote all three kingdoms were ruled by one king based in Neustria (with the already-mentioned exception of Chlothar IV). Nevertheless, the later author was less concerned than Fredegar with the problem of child-kings, who seem to have become a normal part of the political life of the kingdom by the beginning of the eighth century. It may be for this reason the $L H F$-author reserves the highest praise for those kings who were remembered as peace-keepers. In this

\footnotetext{
${ }^{68}$ For example, Fredegar, iii.59, iv.27-30, 36. On Fredegar's attitude to women more generally, see Wood 1994: $361-2$.
} 
sense he shared Fredegar's high opinion of Chlothar II, ${ }^{69}$ but also particularly well-thought of were Dagobert I - who was compared positively with Solomon (with no mention made of the alleged decadence found in Fredegar's account) - and Childebert III - remembered as a just ruler. ${ }^{70}$ Meanwhile, Childeric II, who first ruled Austrasia and then all three kingdoms after the death of his brother Chlothar III in 673, was criticized not simply because he was Austrasian, but because he was 'too frivolous' and 'incautious' and 'caused the greatest hatred and scandal among the Franks' and 'greatly oppressed them'. ${ }^{71}$ In other words, he did not act in concert with the leading men of the kingdom, a key part of the way in which later Merovingian society functioned. ${ }^{72}$

For the $L H F$-author, kings were not expected to lead the Franks in war. Instead they acted as figureheads for Frankish unity, a role which could be fulfilled by a king whatever his age. But these kings also represented a sense of continuity in community's history, as we can see from the way the $L H F$-author notes their dynastic succession: from Theuderic III onwards, the relationship of each king to his predecessor (usually his brother or father) is explicitly noted. The presentation of the last two kings to appear in the text highlight this importance. ${ }^{73}$ Chilperic II represents a rather glaring exception to the rule of dynastic succession. He was made king by the Neustrians after the deaths of Dagobert III in 715 and the mayors Pippin II and his son Grimoald II in the previous year. ${ }^{74}$ These years had seen the kingdoms descend into civil war, and the Neustrians clearly felt their new king gave them a chance of reasserting their dominance over the Austrasians. Certainly, the $L H F$-author acknowledged Chilperic's abilities as a war-leader, although this remained acknowledgement rather than praise. The problem with Chilperic was that he was not the son of the previous

\footnotetext{
${ }^{69}$ Whom the author also portrayed as a successful military leader: $L H F, 41$.

${ }^{70}$ LHF , 40-3, 49-50. See Kershaw 2011: 129; Dörler 2013: 35-7.

${ }^{71} \mathrm{LHF}, 45$.

72 See Gerberding 1987: 146-72; Fouracre and Gerberding 1996; Fouracre 1996.

${ }^{73}$ Discounting the short-lived Chlothar IV; see $L H F, 53$.

${ }^{74}$ LHF , 51-2.
} 
king. Indeed, as the $L H F$-author has it he was not the son of any previous king: all the author says of his accession is 'the Franks established in the kingdom a former cleric named Daniel whose hair had grown back on his head and they called him Chilperic' ${ }^{75}$ In his charters, Chilperic claimed to be the son of Childeric II, ${ }^{76}$ but in $L H F$ he is little more than an imposter, even if having been appointed by the Franks gave him some legitimacy. Given the importance of the later Merovingians in keeping the peace of the community, the report of Chilperic's refusal to accept the Austrasian leader Charles Martel's offer of peace before the Battle of Vinchy may also be a tacit criticism of the king. ${ }^{77}$ In any case, while Chilperic may have been the last of the Merovingians to assert any kind of independence, ${ }^{78}$ he does not come off well in $L H F$ : in summary, he was of dubious legitimacy and did not act like a later Merovingian should.

Conversely, the author says little of Theuderic IV; in fact, despite writing in the king's sixth year he reports nothing after Theuderic's accession. The reason for this is clear, though. While the reconciliation between Chilperic II and Charles Martel in 718 effectively brought the civil war to an end, this was not quite enough for the $L H F$-author. Instead he goes on to report the last crucial detail; that following Chilperic's death 'The Franks set up Theuderic over them as king... he was a son of Dagobert [III] $].{ }^{79}$ With this simple statement the author shows that the stability of the Frankish community has returned and the consensus through which political decisions are made has been restored: the Franks are once again able to choose their own king, and he is a descendant of Theuderic III. The importance of this final statement for the $L H F$-author's vision of the Frankish community is revealed by contrasting it with the way early Carolingian sources report the same events: two examples will suffice,

\footnotetext{
$75 \mathrm{LHF}, 52$.

${ }^{76}$ Most explicitly in Diplomata regum Francorum e stirpe Merowingica, 84-5 and 90, in which Childeric is referred to as 'genitor noster'. This would have made Chilperic at least 40 on his accession (Wood 1994: 268).

${ }^{77} \mathrm{LHF}, 53$.

78 Wood, 1994: 271-2.

${ }^{79} \mathrm{LHF}, 53$.
} 
both of which based their accounts on $L H F$ to a greater or lesser extent. In the so-called Continuations to the Chronicle of Fredegar, probably composed around the $770 \mathrm{~s},{ }^{80}$

Theuderic's accession is noted, but the fact that he was a son of Dagobert III is not: this was apparently no longer an importance aspect of his accession. ${ }^{81}$ In the Annales Mettenses Priores, composed c. 805, Theuderic is passed over in silence, and Charles Martel appears to take up sole rule of the kingdom after Chilperic II's death. ${ }^{82}$ The latter source also claims it was Charles's father Pippin II who appointed Chilperic's predecessors Clovis III, Childebert III and Dagobert III. ${ }^{83}$ We can thus see that by the beginning of the ninth century Frankish historians had a very different conception of the way later Merovingian succession had worked. For the $L H F$-author there was a balance to be found in the interactions between dynastic succession and the act of the Franks in elevating their kings. This had begun to fade in the Continuations, while for the author of the Annales Mettenses Priores everything was in the hands of the Carolingians.

\section{Conclusions: Continuity and Change}

To conclude, we shall consider the central question of this volume: Can we talk about continuity in the seventh century? While we have only addressed a very specific aspect of the question here, it is a crucial one. From a brief examination of the Chronicle of Fredegar and $L H F$ we can, inevitably, see both continuity and change in the ways the authors approached the Frankish community. For both there was a sense of 'the Franks' as a tangible and relevant social idea through which they could write about past events. The Franks were not just a contemporary creation, though: they had a long and continuous history which stretched back to the Trojan War and which had seen the Franks first establish their own group identity and then consolidate this by gaining independence from Roman rule and undertaking their own

\footnotetext{
${ }^{80}$ See Collins 2007: 92.

${ }^{81}$ Fredegarii continuationes, 10.

${ }^{82}$ Annales Mettenses priores, s.a. 718-25. For the date see Fouracre and Gerberding 1996: 332-3.

${ }^{83}$ Annales Mettenses Priores, s.a. 693, 711.
} 
wars of conquest. That this was a group entity is shown in both sources first by the importance of interaction between the members of the community, even if they belonged to different kingdoms or sub-groups of the larger unit, and second by the fact that the most important actions are undertaken not by individuals but by the group. Of course, there were important individuals within this community but these rulers were most likely to be seen positively by posterity if they acted in concert with the leading men of the kingdoms; with the Franks.

This overall picture actually shows a great deal of continuity, but there are signs of change in some of the details. For example, there were clearly different versions of the Trojan origin story circulating in the seventh century. Likewise, the precise connotations of being a 'Frank' were a matter of perception. Perhaps most importantly we can see that what it meant to be a good king changed, with Fredegar emphasising ability in war and the $L H F$-author ability in peace. Nevertheless, these details represent a discourse which ultimately shows continuity. Over the course of the seventh century the idea of a Frankish community emerged and became consolidated to the point that authors writing about the history of the Frankish kingdoms did so not in terms of the region's Church, as Gregory of Tours had done, but in terms of the Franks themselves. The differences we can see in the sources show that their authors were not writing from perspectives which focussed on different communities, but rather from different perspectives of the same community. In other words, both Fredegar and the $L H F$-author believed in the existence of a Frankish community composed of multiple groups of Franks, who were descended from exiles of Troy and ruled over by members of the Merovingian dynasty, even if they approached this community in somewhat different ways. 


\section{Bibliography}

\section{Primary sources}

Ammianus Marcellinus, Res Gestae. Ed. and trans. J. C. Rolfe, 3 volumes, London: Heinemann, 1950-1952.

Annales Mettenses priores. Ed. B. de Simson, MGH Scriptores rerum Germanicarum in usum scholarum separatim editi 10, Hanover: Hahn, 1905.

Diplomata regum Francorum e stirpe Merowingica. Ed. G. H. Pertz, MGH Diplomata Imperii 1, Hanover: Hahn, 1872.

Einhard, Vita Karoli Magni. Ed. O. Holder-Egger, MGH Scriptores rerum Germanicarum in usum scholarum separatim editi 25, Hanover: Hahn, 1911.

Fredegar = Chronicarum quae dicuntur Fredegarii Scholastici libri IV. Ed. B. Krusch, MGH Scriptores rerum Merovingicarum 2, Hanover: Hahn, 1888. Partial ed. and trans. in J. M. Wallace-Hadrill, The Fourth Book of the Chronicle of Fredegar with its Continuations, London: Nelson, 1960.

Fredegarii continuationes. Ed. B. Krusch, MGH Scriptores rerum Merovingicarum 2, Hanover: Hahn, 1888. Ed. and trans. J. M. Wallace-Hadrill, The Fourth Book of the Chronicle of Fredegar with its Continuations, London: Nelson, 1960.

Gregory, Histories = Gregoy of Tours, Decem libri historiarum. Ed. B. Krusch and W. Levison, MGH Scriptores rerum Merovingicarum 1.1 ( $2^{\text {nd }}$ edition), Hanover: Hahn, 1937-1951.

Isidore of Seville, Etymologiae. Ed. W. M. Lindsay, Oxford: Oxford University Press, 1911.

Jonas of Bobbio, Vita Columbani. Ed. B. Krusch, MGH Scriptores rerum Merovingicarum 4, Hanover: Hahn, 1902.

$L H F=$ Liber Historiae Francorum. Ed. B. Krusch, MGH Scriptores rerum Merovingicarum 2, Hanover: Hahn, 1888.

Origo gentis Langobardorum. Ed. G. Waitz, MGH Scriptores rerum Langobardicarum et Italicarum 1, Hanover: Hahn, 1878.

Pactus legis Salicae. Ed. K. A. Eckhardt, MGH Leges nationum Germanicarum 4.1, Hanover: Hahn 1962.

Paul the Deacon, Historia Langobardorum. Ed. G. Waitz, MGH Scriptores rerum Langobardicarum et Italicarum 1, Hanover: Hahn, 1878.

Vita Balthildis. Ed. B. Krusch, MGH Scriptores rerum Merovingicarum 2, Hanover: Hahn, 1888.

\section{Secondary literature}

Anderson, B. (1983). Imagined Communities: Reflections on the Origin and Spread of Nationalism. London: Verso.

Aubrichs, W. (2007). 'Germanic and Gothic Kinship Terminology'. In S. J. Barnish and F. Marazzi (eds), The Ostrogoths From the Migration Period to the Sixth Century: An Ethnographic Perspective, 143-82. Woodbridge: Boydell Press.

Barlow, J. (1995). 'Gregory of Tours and the Myth of the Trojan Origins of the Franks', Frühmittelalterliche Studien, 29, 86-95. 
Broome, R. (forthcoming). 'Pagans, Rebels and Merovingians: Otherness in the early Carolingian world'. In C. Gantner, R. McKitterick and S. Meeder (eds), The Resources of the Past in Early Medieval Europe. Cambridge: Cambridge University Press.

Collins, R. (1996). 'Fredegar'. In P. J. Geary (ed.), Authors of the Middle Ages vol. IV nos. 12-13, 73138. Aldershot: Variorum.

— (2007). Die Fredegar-Chroniken. Hanover: Hahnsche Buchhandlung, 2007.

Corradini, R., Diesenberger, M., and Reimitz, H. (eds) (2003). The Construction of Communities: Texts, Resources and Artefacts. Leiden: Brill.

Diesenberger, M. (2003). 'Hair, Sacrality and Symbolic Capital in the Frankish Kingdoms'. In Corradini, Diesenberger and Reimitz (eds) 2003, 173-212.

Dörler, P. (2013). 'The "Liber Historiae Francorum" - a Model for a New Frankish Self-confidence', Networks and Neighbours, 1, 23-43.

Dutton, P. E. (2004). Charlemagne's Mustache and Other Cultural Clusters of a Dark Age. New York: Palgrave Macmillan.

Ewig, E. (1976). 'Die Fränkischen Teilreiche im 7. Jahrhundert (613-714)'. In E. Ewig (ed.), Spätantikes und Fränkisches Gallien: Gesammelte Schriften, vol. 1, 172-230. Munich: Artemis Verlag, 1976.

Fischer, A. (forthcoming). 'Rewriting History: Fredegar's Perspectives on the Mediterranean'. In A. Fischer and I. Wood (eds), Western Perspectives on the Mediterranean: Cultural Transfer in Late Antiquity and the Early Middle Ages, 400-800 AD.

Fouracre, P. (1998). 'The Nature of Frankish Political Institutions in the Seventh Century'. In Wood (ed.) $1998,285-316$.

- (2008). 'Forgetting and Remembering Dagobert II: The English Connection'. In P. Fouracre and D. Ganz (eds), Frankland: The Franks and the World of the Early Middle Ages, 70-89. Manchester: Manchester University Press.

— Manchester: Manchester University Press.

Gerberding, R. A. (1987). The Rise of the Carolingians and the 'Liber Historiae Francorum'. Oxford: Clarendon.

Goetz, H.-W., Jarnut, J., and Pohl, W. (eds) (2003). Regna and Gentes: The Relationship between Late Antique and Early Medieval Peoples and Kingdoms in the Transformation of the Roman World. Leiden: Brill.

Goffart, W. (1963). 'The Fredegar Problem Reconsidered', Speculum, 38, 206-41. (1988). The Narrators of Barbarian History: Jordanes, Bede, Gregory of Tours and Paul the Deacon. Princeton: Princeton University Press.

Halsall, G. (1998). 'Social Identities and Social Relationships in Early Merovingian Gaul'. In Wood (ed.) 1998, 141-75.

James, E. (1998). 'Gregory of Tours and the Franks'. In A. C. Murray (ed.), After Rome's Fall: Narrators and Sources of Early Medieval History, 51-66. Toronto: University of Toronto Press.

Kershaw, P. J. E. (2011). Peaceful Kings: Peace, Power, and the Early Medieval Political Imagination. Oxford: Oxford University Press.

Krusch, B. (1882). 'Die Chronicae des sogenannten Fredegar', Neues Archiv der Gesellschaft für ältere deutsche Geschichtskunde, 7, 247-351 and 421-516.

Lot, F. (1914). 'Encore la Chronique du Pseudo-Frédégaire', Revue Historique, 115, 305-337. 
Mayr-Harting, H. (1996). 'Charlemagne, the Saxons, and the Imperial Coronation of 800', English Historical Review, 111, 1113-1133.

Murray, A. C. (1983). Germanic Kinship Structure: Studies in Law and Society in Late Antiquity and the Early Middle Ages. Toronto: Pontifical Institute of Mediaeval Studies.

Picard, J.-M. (1991). 'Church and Politics in the Seventh Century: The Irish exile of King Dagobert II'. In J.-M. Picard (ed.), Ireland and Northern France, 27-52. Blackrock: Four Courts Press.

Nelson, J. L. (1996). 'Gender and Genre in Women Historians of the Early Middle Ages'. In J. L. Nelson (ed.), The Frankish World, 750-900, 183-97. London: Hambledon Press.

Pohl, W., Gantner, C., and Payne, R. (eds) (2012), Visions of Community in the Post-Roman World: The West, Byzantium and the Islamic World, 300-1100. Farnham: Ashgate.

Reimitz, H. (2003). 'Social Networks and Identities in Frankish Historiography: New Aspects of the Textual History of Gregory of Tours'. In Corradini, Diesenberger and Reimitz (eds) 2003, 229 268.

- (2006). 'The Art of Truth. Historiography and Identity in the Frankish World'. In R. Corradini, R. Meens, C. Possel, and P. Shaw (eds), Texts and Identities in the Early Middle Ages. Wien: Österreichischen Akademie der Wissenschaften.

- (2012). 'The Providential Past: Visions of Frankish Identity in the Early Medieval History of Gregory of Tours' 'Historiae' (sixth-ninth century)'. In Pohl, Gantner and Payne (eds) 2012, 109-35.

- (2013). 'Cultural Brokers of a Common Past: History, Identity and Ethnicity in Merovingian Historiography'. In W. Pohl and G. Heydemann (eds.), Strategies of Identification: Ethnicity and Religion in Early Medieval Europe, pp. 257-301. Turnhout: Brepols, 2013.

_ (forthcoming). Writing for the Future. History, Identity, and Ethnicity in the Frankish World (550-850). Princeton: Princeton University Press.

Wallace-Hadrill, J. M. (1960). 'Introduction'. In J. M. Wallace-Hadrill, The Fourth Book of the Chronicle of Fredegar with its Continuations, ix-lxvii. London: Nelson.

Wenskus, R. (1961). Stammesbildung und Verfassung: Das Werden der frühmittelalterlichen gentes. Cologne: Böhlau.

Wood, I. (1994). The Merovingian Kingdoms 450-751. London: Longman. (1994). 'Fredegar's Fables'. In A. Scharer and G. Scheibelreiter (eds), Historiographie im frühen Mittelalter, 359-66. Vienna: Oldenbourg.

— (1995). 'Defining the Franks: Frankish Origins in Early Medieval Historiography'. In S. Forde, L. Johnson and A. V. Murray (eds), Concepts of National Identity in the Middle Ages, 47-57. Leeds: Leeds Studies in English.

— (ed.) (1998). Franks and Alamanni: An Ethnographic Perspective. Woodbridge: Boydell Press.

— (2003). 'Deconstructing the Merovingian Family'. In Corradini, Diesenberger and Reimitz (eds) 2003, 149-71.

Zöllner, E. (1970). Geschichte der Franken bis zur Mitte des sechsten Jahrhunderts. Munich: Beck. 